\title{
A New Application of the SERVQUAL Method for the Evaluation of the Quality of Medical Services
}

\author{
Paweł Węgłowski ${ }^{1}$, Iwona Mazur², Joanna A. Jończyk ${ }^{3}$, Michał Czapla ${ }^{2}$, \\ Piotr Karniej ${ }^{2}$
}

1 Department and Clinic of Paediatric Nephrology, Faculty of Medicine, Wroclaw Medical University, Poland

2 Department of Public Health, Faculty of Health Sciences, Wroclaw Medical University, Poland

3 Department of Organisation and Management, Faculty of Engineering Management, Bialystok University of Technology, Poland

\begin{abstract}
This study was designed to determine the quality of service through the evaluation of hospitalized patients. An analysis of hospitalized patients' subjective feelings towards service quality was carried out, in the context of the application of the SERVQUAL method. The pilot study was conducted in a Silesian hospital in a group of 29 young patients (women: 16, men: 13, average age: 16) diagnosed with kidney disease. The study used a standard sheet of 22 SERVQUAL statements and an analysis of the significance of the 5 areas of quality material important for the patient. According to the respondents, the most important of the 5 features that influence the quality of life is the ability of the ward staff to provide adequate medical services $(24.48 \%$.) The least important were the aesthetics and ergonomics of rooms (15.31\%). Service quality gaps were seen in all the five dimensions as well as in the overall service quality. Hence, the following conclusions could be made: 1. The SERVQUAL method helps to identify discrepancies between perceptions of patients' expectations in all the dimensions of quality of medical services. 2. For patients, the least important is the material dimension, whereas the one most affecting them is the dimension associated with the reliability of medical services. 3. An improvement of the level of satisfaction with the quality of medical services requires proper planning and effectiveness of implementation of health care services. 4. Research should be conducted on a larger population of patients.
\end{abstract}

\section{Introduction}

The quality of medical services has for many years been a subject of interest for both theorists and medical professionals. Therefore, the concept of "medical quality" is considered an interdisciplinary formulation, analyzed and defined from the point of view of medicine, psychology, sociology, philos- 
ophy, and social economy. Accompanying this phenomenon, the term "quality of life" was introduced in the USA (Gętek et al., 2010; Rutkowski, 2008); with A. Campbell, F. Andrews and S. Whitney among the pioneers in the field. They started their work to assess the level of life satisfaction in American society (Gętek et al., 2010; Sapilak et al., 2006). The goal was to achieve a comprehensive improvement in the quality of life, although initially the attention was paid only to the area of material goods. Years of observation showed that improving the quality of life of a patient is a relevant aspect also in the areas of education, health, freedom, and happiness.

As far as quality of life is concerned, the term "health related quality of life" (HRQoL) should be mentioned, formulated on the basis of WHO's definition of health as "the functional effect of the disease and its treatment received by the patient" (Gętek et al., 2010; Rutkowski, 2008). The difference between the state of health - assessed objectively by the patient on the basis of symptoms from different organs and the quality of life determined by a subjective health condition, which may change over time - has also been emphasized (Gętek et al., 2010; Rutkowski, 2008).

The quality of life of patients is connected with broadly understood medical, occupational and psychosocial rehabilitation and depends on determinants such as: the patient's age, type of illness, treatment possibilities, duration of the illness, individual psychophysical conditions, and environmental support (Gętek et al., 2010; Ostrzyżek, 2008; Wojtaszek \& MatuszkiewiczRowińska, 2008). Both adult and paediatric patients need professional medical assistance to help them cope with the illness at its every stage, and even more so during hospitalization.

As patient awareness increases, more attention is paid to the relationship between the patient and the medical staff in both open and closed health care. Patients expect modern diagnostic, therapeutic and professional procedures from the "staff in white". Despite the high standard of medical services, most patients associate a stay in a hospital with a subjectively lower quality of life. In the analysed case, the perceived quality of life is linked with the quality of the health service. Therefore, the assessment of the quality of medical services is associated with the patient's expectations as well as their feelings/impressions on the service received. According to Grönroos (1990), the quality of health services has two dimensions: technical quality and functional quality. Technical quality of health services is the basis for identifying the authenticity of procedures and management, whereas functional quality is related to preclinical aspects (Nekoei-Moghadam \& Amiresmaili, 2011). In order to ensure that medical procedures are not only effective from the expert's point of view but also have the capacity to meet patient expecta- 
tions as to the quality of their functioning, the said expectations have to be considered on the basis of the access to healthcare systems. Hence, it is important to evaluate services directly and indirectly from the perspective of the patient (Nekoei-Moghadam \& Amiresmaili, 2011). Providing services that meet patient needs and expectations is essential for the development of the medical industry in a competitive environment, which is undoubtedly a feature of the health care market (Lee et al., 2000).

There are various ways to define patient expectations, the SERVQUAL method being among the most effective and widely used, mainly to examine the relationship between the service - from an economic point of view - and the customer. Only a small number of reports on the use of SERVQUAL in the assessment of hospital services can be found in the available literature, which may also affect the quality of life of patients.

The tool in question is used to measure the quality of service; it has five dimensions and 22 elements to measure patient expectations and perceptions (Zeithaml \& Bitner, 1996). SERVQUAL accurately assesses the satisfaction and impact on quality perception of the patients they receive and compares them to their ideal expectations. Parasurman believes that the quality of service is related to patient expectations before and after the delivery of the medical service. The service gap, resulting from the difference between customer expectations and perceptions, is also identified. The model is also considered to be the model of slot between gaps analyser and is the strongest available tool for the evaluation of the quality of service (Brooks et al., 1999).

\section{Aim of the Study}

The aim of the study is to adapt the SERVQUAL method to the assessment of the quality of medical services, particularly to a subjective assessment of the medical service provided to hospitalized patients.

\section{Materials and Methods}

The survey was conducted in one of the Lower Silesian hospitals in the period from December 2015 to March 2016. It was sufficient to obtain oral consent from the patients or their legal guardians.

The study population consisted of 29 people, including women (W): $16(55.1 \%)$ and men (M): $13(44.9 \%)$. In the study group, 9 patients $(31.03 \%)$ were 15 years old (W: 7, M: 2), 8 patients $(27.59 \%)-16$ years old (W: 4, M: 4), whereas 38\% indicated their age as 17 (W: 5, M: 7) in the survey questionnaire. The following group selection criteria were chosen de- 
liberately considering the need for informed opinion, i.e. children over 15 , able to co-decide, currently staying in the hospital for a minimum of two days (confirmed with another hospital stay). The questionnaire was discussed with the interviewees, before being filled in with an assistance of an experienced interviewer. The PAPI method was used and the questions were formulated in a way comprehensible to respondents. The reason for the surveyed patients' hospitalization was the need to perform procedures related to the diagnosis or treatment of diseases of the urinary tract. In the study population, 27 patients $(93.1 \%)$ were active in school activity; only 2 patients $(6.9 \%)$ did not participate in it. The respondents rated their material and financial situation as mostly good - 20 patients $(68.97 \%)$; 7 patients $(24.14 \%)$ found it average, while 1 patient (3.45\%) described it as bad, and 1 as very good (3.45\%). The respondents were also inquired as to their place of residence. The majority of the hospitalized patients lived in villages; 12 patients $(41.38 \%$ ) lived in towns of up to 10 thousand residents; 6 patients (20.69\%) lived in cities of up to 100 thousand residents; 7 patients $(24.14 \%)$ in cities over 100 thousand residents, and 4 patients indicated their place of residence as the hospital (13.79\%). The measured characteristics of the respondents such as age, sex, place of residence, financial status and school activity are presented in Table 1.

Table 1. Characteristics of the surveyed patients

\begin{tabular}{|c|c|c|c|c|c|c|c|}
\hline \multirow{2}{*}{\multicolumn{2}{|c|}{ Characteristics of the respondents }} & \multicolumn{2}{|c|}{ Women } & \multicolumn{2}{|c|}{ Men } & \multicolumn{2}{|c|}{ Study sample } \\
\hline & & \multirow{2}{*}{$\begin{array}{l}\mathrm{N} \\
16 \\
\end{array}$} & \multirow{2}{*}{$\begin{array}{c}\% \\
55.1 \\
\end{array}$} & \multirow{2}{*}{$\frac{\mathrm{N}}{13}$} & \multirow{2}{*}{$\begin{array}{c}\% \\
44.9 \\
\end{array}$} & \multirow{2}{*}{$\begin{array}{c}\mathrm{N} \\
29\end{array}$} & \multirow{2}{*}{$\begin{array}{c}\% \\
100 \\
\end{array}$} \\
\hline & & & & & & & \\
\hline \multirow{3}{*}{ Age } & 17 & 5 & 31.25 & 7 & 53.85 & 12 & 41.38 \\
\hline & 16 & 4 & 25 & 4 & 30.77 & 8 & 27.59 \\
\hline & 15 & 7 & 43.75 & 2 & 15.38 & 9 & 31.03 \\
\hline \multirow{4}{*}{ Place of residence } & village & 3 & 18.75 & 9 & 69.24 & 12 & 41.38 \\
\hline & up to 10 thousand & 4 & 25 & 2 & 15.38 & 6 & 20.69 \\
\hline & up to 100 thousand & 6 & 37.5 & 1 & 7.69 & 7 & 24.14 \\
\hline & over 100 thousand & 3 & 18.75 & 1 & 7.69 & 4 & 13.79 \\
\hline \multirow{4}{*}{ Financial situation } & very good & 0 & 0 & 1 & 7.69 & 1 & 3.45 \\
\hline & good & 13 & 81.25 & 7 & 53.85 & 20 & 68.97 \\
\hline & average & 3 & 18.75 & 4 & 30.77 & 7 & 24.14 \\
\hline & bad & 0 & 0 & 1 & 7.69 & 1 & 3.45 \\
\hline \multirow{2}{*}{ School activity } & yes & 14 & 87.5 & 13 & 100 & 27 & 93.10 \\
\hline & no & 2 & 12.5 & 0 & 0 & 2 & 6.90 \\
\hline
\end{tabular}

$\mathrm{N}$ - number of respondents 
For the purposes of own research, the basic version of the SERVQUAL questionnaire was used to demonstrate the difference between the expected quality and patient experience in the service/service components concerned.

This questionnaire consisted of 22 questions on various spheres of life, divided into 5 categories:

1. Material dimension - visual appearance and interiors of the hospital, cleanliness, appearance of staff, quality of meals, medical and other equipment, media (information in the facility, markings) - 5 statements.

2. Reliability - ability to deliver the service consistent with the offer, reliability, accuracy of procedures -5 statements.

3. Willingness - willingness to meet patient expectations, willingness to help patients and their carers, efficiency at admission to hospital, quality and reliability of information about treatment plans -4 statements.

4. Expertise and trust - professionalism and trust, professional knowledge and skills, courtesy and ability to create confidence and trust, respect for patient intimacy -3 statements.

5. Empathy - individual approach to the patient understood as giving attention to each patient, ability to identify the patient's needs, ability to appreciate the patient's situation, meeting their needs for external contacts -5 statements.

In the SERVQUAL method, the test results are calculated on the basis of average scores for each of the questions. Assessment is then made for the expected quality and the quality experienced by patients in a given dimension. In this way, there are three possible situations:

1. Expected quality $=$ quality experienced

2. Expected quality $>$ experienced quality

3. Expected quality $<$ experienced quality

The survey makes use of a five-point Likert scale of $1-5$, with figure 1 (in the case of patient assessment) meaning that the factor was insignificant and 5 that the factor was very important. In the case of the assessment of the quality of the received service, number 1 meant "very low" for a given factor whereas 5 meant "very high". Then, according to the SERVQUAL model, a pool technique was used to divide 100 points between 5 quality dimensions, to determine their validity (significance, impact on perception of the quality of life) for patients. First, the respondents assessed their expectations as far as the hospital stay is concerned and then assessed the benefits and the services received in the unit. 
Pawet Weglowski al.

\section{Results}

As shown in Figure 1, the respondents assessed the level of the expected quality and the level of the quality delivered to them through the medical service. Based on the research results, the average "waiting score" was high - 97.64 points. Among the five quality dimensions (Likert scale 1-5), the respondents showed the highest expectations for the "readiness" dimension (98.8 points). The lowest expectations were related to the "empathy" dimension (97.2 points). In addition, the participants indicated the dimensions that they believe have the greatest impact on quality in the context of the medical service provided. According to the respondents, the dimension which influenced the perception of the quality of life most strongly was the "reliability" dimension ( 87 points), whereas the least tangible dimension turned out to be the "material" dimension with 61.3 points.

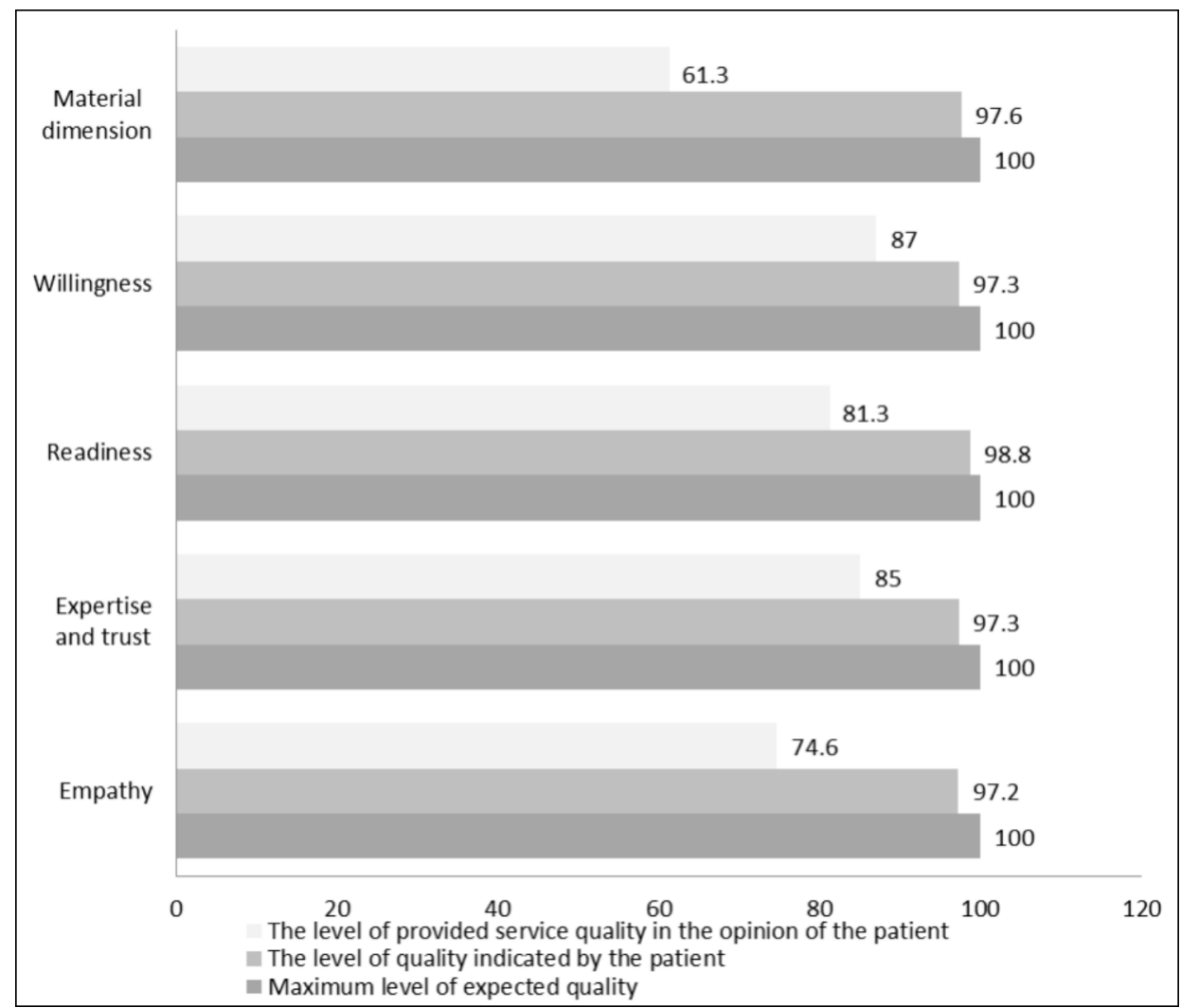

Figure 1. Evaluation of the significance of the quality dimensions taking into account the difference between the expected quality and the patient experience 
A New Application of the SERVQUAL Method for the Evaluation...

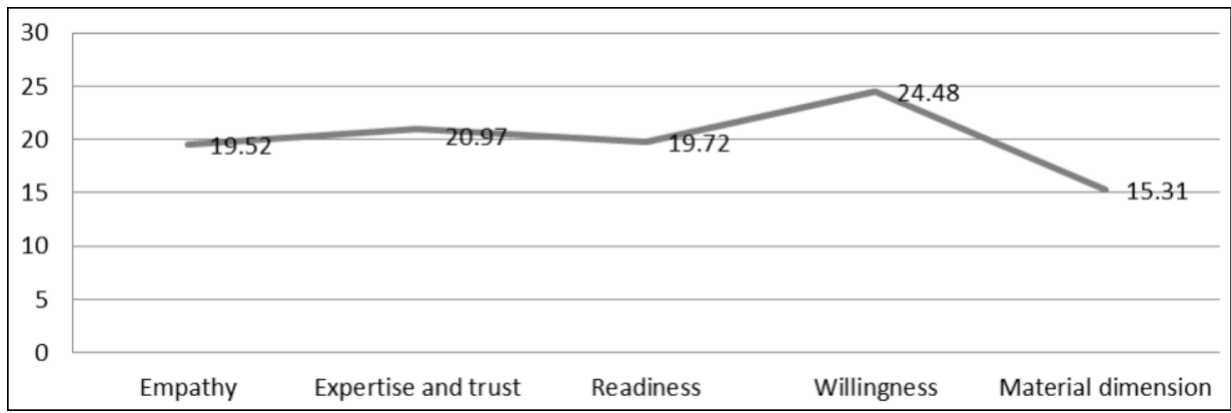

Figure 2. Significance of quality dimensions according to patients

Figure 2 presents the quality dimension according to the surveyed patients.

In the course of the assessment, the respondents attached the greatest importance to the "reliability" dimension $(24.48 \%)$, followed by "professionalism and trust", "readiness", and "empathy". The "material" dimension was indicated by the respondents as the least affecting (15.31\%).

\section{Discussion}

Each medical facility providing outpatient and inpatient services seek to improve the quality and satisfaction of patients by monitoring the procedures being implemented. Hospital staff, especially those in direct contact with patients, have the most significant impact on the quality of hospital services and, consequently, patient satisfaction. According to the perceptions of the surveyed patients, the "reliability" dimension (24.48\%) was the most desirable aspect of the quality of service, followed by professionalism and trust (20.9\%). The two latter characteristics also describe the high quality of medical services provided by a hospital. In a study conducted in a private Iranian hospital, the "reliability" dimension was considered by the respondents as the most important factor in assessing the quality of medical services. The dimension of empathy ranked second in the view of the Iranian patients (Zarei et al., 2012). On the other hand, the material dimension was the least important for the Iranians. In a study by Lewandowski (2008), conducted in the paediatric hospital as well, the most important dimension from the patient's point of view was "readiness to meet the patient's expectations" and then the "material" dimension. The results of a survey conducted by Aghamolaei's team (2014) were similar to those obtained by Lewandowski (2008), with the most important dimen- 
sion in the quality of medical services also being "readiness". Classified as first, however, was the dimension of "empathy" (Aghamolaei et al., 2014). Wolniak (2010) and Wereda \& Jończyk (2016) show that the highest patient expectations can be observed in the case of variables included in the "readiness" area, and the patients are least satisfied with the variables related to "empathy". The area of "materiality", in a study by Domowicz (2013), was classified as the least important, while the greatest importance was attached to the variables from the area of "empathy". In the case of our respondents, the dimension of "materiality" was the least significant, while in the survey carried out by Lewandowski (2008), this dimension occupied the high $2^{\text {nd }}$ place. Thus, the results of research studies into the implementation of the SERVQUAL method in other areas of health care seem to be confirmed. Manulik et al. (2016) show the adaptability of this method in the context of outpatient specialist care.

The methodological point of view applied in this paper is the use of deliberate sample selection instead of randomized trials. It should be noted that the study was conducted in a field of medicine where no research from the medical or economic sciences has been conducted so far, and for this reason the quality of the service has not been explicitly defined by these criteria. In addition, a significant limitation of a randomized trial is the limited access to the patient population, as it would entail obtaining consent for a follow-up in addition to consent of the patient or parent. In the face of such limitations, a trial with a deliberate sample selection appears to be an optimal solution. This report is of a pilot nature, but it should be emphasized that this methodology is not intended to change in the main study as well. The accepted sample selection criteria and the ensuing inference may, in the authors' opinion, form the basis for further interpretation, due to the comparability of the course of the disease itself, which an obvious common element for the surveyed subjects.

The results of quality tests of medical services presented above differ from the authors' data. This difference is probably due to cultural differences and the different patient expectations as far as health services are concerned. Nevertheless, all patients consider their own well-being as seen from the perspective of improving their health of the utmost importance, and there are various "paths" that can lead to achieving this aim. In addition, our results show that the lowest expectation was related to the "material" dimension and "empathy". Our respondents' expectations are high in all the dimensions of service. Moreover, patient expectations were higher than their perception of the quality of service. The highest negative gap 
was found in the "material" dimension. Negative gaps indicate that patient expectations in the context of the services provided are higher than their perceptions, which - in the opinion of the surveyed patients and from the point of view of the study - affect the perception of the quality of life in relation to these dimensions to the least extent.

The present survey shows that patients pay attention not only to the clinical aspects of their disease, but also to other related areas, which have a direct impact on the perception of the quality of the medical services provided to them. Therefore, the impact on patient perception and their quality of life is determined not only by doctors, but also by many dimensions of life (as mentioned: the material dimension, reliability, readiness, professionalism and trust, and empathy). Using the SERVQUAL method, the features of medical services that are seen by hospitalized patient as the most important ones can be recognized, as well as those that do not fully meet patient expectations. Attention should also be paid to the fact that many publications on the application of the SERVQUAL method to the quality assessment of medical services in conservative hospitals have failed, according to the Polish scientific literature. Therefore, a preliminary hypothesis has been put forward that the quality measurement model of SERVQUAL is a tool for measuring the quality of hospital services in the subjective view of hospitalized patients.

This research presents its results on the basis of quality assessment of medical services of a single selected hospital ward. In addition, the number of patients surveyed was relatively small, making it possible to make only preliminary conclusions. It is therefore important to conduct further surveys in a larger population of patients in a chosen hospital.

The holistic "approach" to the patient should definitely become the paramount consideration, instead of the predominant focus on the clinical aspects of a disease. Our research also confirms the importance of the role of the medical and nursing staff, who watches over patients during hospitalization. Carrying out conversations with elements of psychotherapy and enhancement of positive stimuli would make use of the results of the evaluation of the quality of medical services according to patients. GPs' knowledge in the area of patient satisfaction with hospital treatment and its conditions plays an important role for the trustee, i.e. the physician-patient relation. The knowledge gained from the answers to the questionnaire may contribute to deinstitutionalisation of patient care. 


\section{Conclusions}

The obtained results show that:

1. The SERVQUAL method helps to identify the discrepancies between patient perceptions and expectations in all the dimensions of the quality of the medical services provided.

2. The SERVQUAL method is an effective tool for monitoring and patients' subjective assessment of the quality of medical services.

3. According to patients, the "material" dimension is the least important whereas the most influential is the dimension of "reliability" of the medical services provided.

4. Improving the level of satisfaction with the quality of medical services requires proper planning and effectiveness of activities during the implementation of medical services.

5. It is advisable to perform this type of study on a larger population of patients.

\section{R E F E R E N C E S}

Aghamolaei, T., Eftekhaari, T. E., Rafati, S., Kahnouji, K., Ahangari, S., Shahrzad, M. E., Kahnouji, A., \& Hoseini, S. H. (2014). Service quality assessment of a referral hospital in Southern Iran with SERVQUAL technique: patients' perspective. BMC Health Services Research, 14: 322. doi: 10.1186/1472-6963-14-322

Brooks, R. F., Lings, I. N., \& Botschen, M. A. (1999). International marketing and customer driven wave fronts. Service Industries Journal, 19(4), 49-67.

Domowicz, B. (2013). Health care quality perception by hospital patients - a preliminary report. Hygeia Public Health, 48(3), 352-354.

Gętek, M., Nowakowska-Zajdel, E., Czech, N., Białek, A., Muc-Wierzgoń, M., \& Kokot, T. (2010). Jakość życia pacjentów dializowanych i po przeszczepie nerek. Annales Academiae Medicae Silesiensis, 64(5-6), 23-30.

Grönroos, Ch. (1990). Service Management and Marketing. Lexington Books.

Lee, H., Delene, L. M., Bunda, M. A., \& Kim, C. (2000). Methods of measuring health-care service quality. Journal of Bussines Research, 48(3), 233-246.

Lewandowski, R. (2008). Pomiar jakości usług medycznych z wykorzystaniem metody SERVQUAL. Problemy Jakości, 9, 30-35.

Manulik, S., Rosińczuk, J., \& Karniej, P. (2016). Evaluation of health care service quality in Poland with the use of SERVQUAL method at the specialist ambulatory health care center. Patient Preference and Adherence, 10, 14351442 . 
Nekoei-Moghadam, M., \& Amiresmaili, M. R. (2011). Hospital services quality assessment: Hospitals of Kerman University of Medical Sciences, as a tangible example of a developing country. International Journal of Health Care Quality Assuance, 24(1), 57-66.

Ostrzyżek, A. (2008). Jakość życia w chorobach przewlekłych. Problemy Higieny $i$ Epidemiologii, 89(4), 467-470.

Rutkowski, B. (Ed.). (2008). Leczenie nerkozastępcze w praktyce pielegniarskiej. Gdańsk: Via Medica.

Sapilak, B. J., Kurpas, D., Steciwko, A. F., \& Melon, M. (2006), Czy jakość życia jest istotna dla chorych dializowanych? Na podstawie 3-letniej obserwacji pacjentów. Problemy Lekarskie, 45(3), 89-93.

Wereda, W., \& Jończyk, J. A. (2016). The role of customer satisfaction in the modern marketing on the example of the market of dental services. Zeszyty Naukowe Szkoły Głównej Gospodarstwa Wiejskiego w Warszawie. Polityki Europejskie, Finanse i Marketing, 16(65), 114-127.

Wojtaszek, E., \& Matuszkiewicz-Rowińska, J. (2008). Rola pielęgniarki w multidyscyplinarnym zespole terapeutycznym w leczeniu pacjentów z przewlekłą chorobą nerek. Nefrologia i Dializoterapia Polska, 12(1), 44-46.

Wolniak, R. (2010). Pomiar oczekiwanej i postrzeganej jakości w usługach medycznych. Współczesne Zarzadzanie. Kwartalnik Środowisk Naukowych i Liderów Biznesu, 2, 135-137.

Zarei, A., Arab, M., Froushani, A. R., Rashidian, A., \& Tabatabaei, S. M. G. (2012). Service quality of private hospitals: The Iranian Patients' perspective. $B M C$ Health Services Research, 12:31. doi: 10.1186/1472-6963-12-31

Zeithaml, V. A., \& Bitner, M. J. (1996). Service Marketing. New York: Mc Graw Hill. 